\title{
IDENTITY MATTERS
}

\section{Defining Muslims}

It is generally believed that all Muslims practise the same aspects of Islamic culture - names, dress codes and eating and drinking habits - and that they are a distinct non-Christian cultural group, separate from the mainstream American population. Yet Muslims in the United States (and elsewhere) are ethnically diverse and heterogeneous in language, skin colour and culture. The only element they have in common is their religion and even that has some variations. Nevertheless, most Muslims feel a strong affiliation with the broader Islamic community (ummah) and have a constant desire for greater Islamic political unity within the 'Abode of Islam' (dar-al-Islam). The centrepiece of unity among Muslims is the Quran the very word of Allah (God). The Quran provides the same message for all Muslims, although interpretations of that message differ across the various Muslim groups and because of the different levels of textual meaning. Muslims' devotional practice rests on what are known as the five pillars of Islam:

1. Kalima (or shahada). Kalima is an open declaration of faith. It has to be said in Arabic, 'La ilaha il-lal-lahu, Muhammadur Rasu-lul-lab', and means: 'I testify (confess) that there is no Allah but the one Allah and that Muhammad is the Messenger of Allah.'

2. Salat. This is the communal prayer that has to be performed five times each day - in the morning (before sunrise), at noon, in the afternoon, at sunset and at night, facing the Ka'bah, an important shrine of the Islamic world in Mecca. Before performing the salat, the believer must be in a state of purity, and therefore needs to carry out a series of ritual ablutions. The 
salat may be performed wherever the Muslim happens to be, though some prefer to pray in mosques.

3. Zakat. This is almsgiving. Muslims are expected to give 2.5 per cent of their net income to other members of the same faith who are less well off or in need.

4. Sawm. This is fasting. During Ramadan, the ninth month of the Islamic calendar, Muslims must refrain from eating, smoking, drinking and sex between sunrise and sunset.

5. Hajj. The fifth pillar is the pilgrimage or visit to Mecca to pray around the Ka'bah, in Zil Haji, the twelfth month of the Islamic calendar. Every Muslim should, if health, financial means and safety of the routes allow, undertake this pilgrimage at least once in his or her lifetime. Men who have performed the hajj are called hajji and women are hajja. ${ }^{1}$

In addition to the five pillars, Muslims must not eat certain foods, such as pork, or drink alcohol. Muslims slaughter animals according to teachings of the Quran called halal, and devout Muslims eat halal meat. Some women choose to wear the hijab and the abaya or burqa to pay due respect to the teachings and tradition of Prophet Muhammad (PBUH) - these teachings are known as the Hadith or Sunnah. In some Muslim countries, such as Saudi Arabia, the wearing of the hijab is mandatory, whereas in other countries, such as Bangladesh, it is a matter of personal choice. Muslims have two important festivals each year: Eid-ul-Fitr, which is celebrated immediately after Ramadan, and Eid-ul-Adha, the feast celebrated after the hajj on the tenth day of Zil Hajj. To mark the pilgrimage to Mecca, Muslims all over the world celebrate the Feast of Sacrifice in Eid-ul-Adha. Sheep are ritually slaughtered to commemorate Prophet Ibrahim's (PBUH) willingness to sacrifice his son. This meat is partly for one's own consumption and the rest is given to friends and distributed among the poor and needy.

Muslims are divided into two main sects, Sunni and Shia. About 87 per cent of all Muslims in the world are Sunnis and about 13 per cent are Shic ite. ${ }^{2}$ There are further divisions among the Sunnis and Shic ites (see Chapter 2), though all believe in the five pillars of Islam.

In this chapter, I begin with a brief history of Muslims in America. Secondly, I examine some of the contemporary issues impacting on American Muslims. Thirdly, I introduce social identity theory and explain how it can help us to understand identity. Fourthly, I discuss my research methodology.

\section{A brief history of Muslims in America}

Muslim contact with America commenced during the 1700s when Muslim slaves were brought from Africa. Records show that a few Muslim slaves in the United States became famous. For example Kunta Kinte, who is depicted in 
Alex Haley's book (and the television show) Roots, was brought from Gambia in $1767 .{ }^{3}$ Kinte tried hard to hold onto his Islamic heritage and showed great courage by practising Islam in a very Christian environment. Some Muslims fought in the Revolutionary War; for example, Peter (Saleem) Salem, a former slave, fought in the Battle of Bunker Hill against British troops in 1775. ${ }^{4}$ Muslim slaves were not allowed to develop institutional structures in the form of mosques or graveyards, so they could not establish an Islamic heritage for their descendants; nevertheless, some slaves such as Kinte and Salem retained their Islamic identity. ${ }^{5}$

Muslims from Syria and Lebanon began to migrate to the industrial cities of the Midwest in small numbers before World War I. More Muslims began to arrive in the inter-war period from Albania, Turkey, Yugoslavia, Syria, Lebanon and the Indian subcontinent. By the early 1920s, mosques had been established in Maine (1915), Connecticut (1919) and Highland Park, Michigan (1919), with others following in Michigan City, Indiana (1925), New York (1926), Pittsburgh (1930) and Sacramento (late 1930s). ${ }^{6}$ The first purpose-built mosque, the Mother Mosque of America, was built in Cedar Rapids, Iowa, in 1934. As the Muslim community grew, the Federation of Islamic Associations of the United States and Canada was founded in 1953. The Muslim presence was gradually recognised by American authorities. In 1954, President Dwight Eisenhower inaugurated the Washington mosque by cutting its ribbon. ${ }^{7}$

After a change in federal immigration law in 1965, a wave of highly educated Arab/Muslim immigrants arrived in the US, to be joined from the 1970s by Muslims from south Asia. Gradually many Muslim organisations were established to address Muslim issues. Some notable ones are the Islamic Society of North America, the Islamic Circle of North America and the Muslim American Society. ${ }^{8}$ The 1950 s and 1960 s also saw two prominent African Americans convert to Black Islam (Nation of Islam), later embracing Sunni Islam: Malcolm X (a radical leader of the Black Power movement) and the boxer Mohammad Ali (formerly Cassius Marcellus Clay Jr).

It is difficult to obtain a definite number for the total Muslim population in the United States at any stage because the US census has never asked citizens to declare their religious affiliation. However, based on its own survey together with its interpretation, the US census data (which provides the racial statistics and country of birth) in conjunction with the Pew Research Center estimated that in 2011 there were 2.75 million Muslims living in the United States, ${ }^{9}$ which comprised 0.88 per cent of the total US population $(312,119,000) \cdot{ }^{10}$ The Pew Research Center further determined the racial composition of the US Muslim population in this order: white 30 per cent, black 23 per cent, Asian 21 per cent, Hispanic 6 per cent, other or mixed race 19 per cent. ${ }^{11}$ The breakdown of the Muslim population according to race is problematic; for example, the category 'white' includes mainstream Americans (Caucasians) 
and Arab Americans (who have lighter skin). Similarly, traditional African Americans (with an enslavement history), and immigrant Africans, such as Algerians, could be lumped together in the 'black' category. In another account, the Pew Research Center provided the US Muslim population according to their place of birth, in this order: US 37 per cent, Middle East (including Iran) and north Africa 29 per cent, Asia (Pakistan and other south Asia) 16 per cent, sub-Saharan Africa 7 per cent, Europe 5 per cent, other 6 per cent. ${ }^{12}$

There have been some eminent Muslims in American society, such as the boxer Muhammad Ali and the basketball player Kareem Abdul-Jabbar in sport, and in art and entertainment the rhythm and blues songwriter and producer Muhammad Luqman Abdul-Haqq (Kenny Gamble) had become famous. ${ }^{13}$ In politics there have been some elected Muslim officials, for example Larry Shaw, a North Carolina senator; Yusuf Abdus-Salaam, a councillor in Selma, Alabama; Kazi Miah, a councillor in Hamtramck, Michigan; John Rhodes, a councillor in North Las Vegas; and Lateefah Muhammad, a councillor in Tuskegee, Alabama. Some have also held important positions: Hassan El-Amin was appointed as a district judge in Prince George County, Maryland; and two Muslims, Osman Siddique, of Bangladeshi origin, and Zalmay Mamozy Khalilzad, of Afghan background, have served as US ambassadors to other countries. ${ }^{14}$ At the time of writing this chapter, there were two African American Muslim Congressmen: Keith Ellison, from Minnesota, and André D. Carson, from Indiana. In 2010, Rima Fakih was the first Muslim woman to become Miss USA.

In previous research in Australia and the UK, I was able to evaluate Muslims' labour market status (employment and unemployment level) by examining the official census data of the respective countries, but not for this study because, as stated above, in the United States there is no official census data by religion. So the total Muslim placement in the American labour market cannot be evaluated.

\section{International events impacting on Muslim Americans}

\section{The Muslim world's news}

From the 1970s to the 1990s, there was a gradual increase in the Muslim population, and during this period Americans were becoming more conscious of Muslims most often through sensational news reports on the Iranian Revolution (1979), the Iranian hostage crisis (1979-81), the Libyan terrorist bombing of Pan Am flight 103 over Lockerbie, Scotland, which killed all 259 passengers (1988), the Salman Rushdie affair (1989) and the Oklahoma bombing (1995). The Iranian hostage crisis was followed by a public backlash against Iranians in the United States characterised by frequent burning of 
Iranian flags, shouts of 'Arab go home' (even though Iranians are not Arabs), and emotional bank tellers refusing to cash Iranian students' cheques. ${ }^{15}$ In 1995, after the bombing of a US federal government complex in Oklahoma by the non-Muslim Timothy McVeigh, some Muslims in America, particularly the Arabs, were vilified by members of the wider community. It was initially speculated by the media that the perpetrator was a Muslim. Then, after the 11 September 2001 terrorist attacks, vilification against Muslims intensified. Paul Barrett observed:

A Gallup poll in 2006 found that four in ten Americans admitted feeling prejudice against Muslims. Nearly one-quarter said that they would not like to have a Muslim as a neighbor. Four in ten would require Muslims to carry special identification cards and undergo more intensive security checks at airports. Among American Muslims, 40 per cent told the Zogby International polling firm in 2004 that they had suffered discrimination since 9/11. Many Muslims in the United States have doubts about whether they are accepted as 'real' Americans. ${ }^{16}$

Since the $9 / 11$ terrorist attacks some people believe that Islam is necessarily a violent creed. Passages of the Quran are sometimes taken out of context as evidence that Islam requires believers to kill or convert non-believers. Some Muslim countries, such as Afghanistan (under the Taliban), Iran, Saudi Arabia and Yemen, have established shariah law and enforced penalties under hudud (the criminal code of shariah law that commands stoning to death of adulterers and other horrific punishments), which has been interpreted by the public at large as evidence that Muslims are backward and violent.

When the Taliban ruled Afghanistan (from the mid-1990s until October 2001) the world witnessed several atrocities. The ultra-conservative Taliban espouse a very strict interpretation of Islam, which is unpopular among the majority of Afghans because it rejects Muslim moderation and the West. As Rashid Ahmed says, 'The Taliban have given Islamic fundamentalism a new face and a new identity for the next millennium - one that refuses to accept any compromise or political system except their own. ${ }^{17}$ The Taliban banned modern technology like the internet and television in Afghanistan during its harsh rule. Under Taliban rule, women were not allowed to work and girls were not allowed to attend school. Men were beaten for trimming their beards and associating with women other than family members. The Taliban executed homosexuals by lapidation, bulldozing walls to crush their bodies. ${ }^{18}$ The Taliban's punishment for adultery made worldwide news. In 1996 an Afghan woman called Nurbibi, aged forty, and her stepson and lover Turyalai, aged thirty-eight, were stoned to death under the provisions for punishing adulterers in shariah law. ${ }^{19}$ In 2001, the Taliban destroyed some 2,000-year-old Buddhist statues in Afghanistan because they regarded them as an insult to Islam.

In 2000 Nigeria's northern states adopted a harsh shariah code. The code's 
first victim who made worldwide news was a woman convicted of adultery, Amina Lawal. In 2002, Lawal was sentenced to death by stoning, and her pregnancy was taken as proof of the adultery. Worldwide condemnation of the case, and a campaign mounted by human rights organisations, eventually led to Lawal's acquittal. If the sentence had been carried out, she would have been buried up to her neck in sand then pelted with rocks. ${ }^{20}$ Many other women convicted of adultery, however, may not be fortunate enough to receive such international attention.

In 2010, an Iranian woman, Sakineh Mohammadi Ashtiani, who was also convicted of adultery, made worldwide news. Ashtiani was found to have had 'illicit relationships' with two men after the death of her husband, and was initially sentenced to ninety-nine lashings. But, after she was flogged in front of her teenage son, the case was reopened and the judge ultimately ordered the death penalty, sentencing her to a violent end. Ashtiani had already spent five years in prison, and her children were horrified by her sentence. An international human rights group worked for her acquittal and it was reported that Tehran had provisionally suspended the death sentence. ${ }^{21}$ Despite these wellpublicised reprieves, the news of the application of the hudud in some Muslim countries, such as stoning to death for adultery, or public hanging for armed robbery, rape or other offences, ${ }^{22}$ reinforces public opinion that all Muslims are brutal.

Such ongoing news from the Muslim world has no doubt added to mainstream Americans' negative perception of Muslims. For example, when the Israeli-Palestinian peace talks commenced in Washington, DC in 2010, the hardline Iranian president, Mahmoud Ahmadinejad, told a pro-Palestinian rally of thousands of Iranians that revived Middle East peace talks were 'doomed' to fail. Ever since the 1979 revolution, Iran has organised annual Palestinian solidarity marches across the country on al-Quds Day, the last Friday of Ramadan. Tens of thousands of Iranians rally in streets around the country shouting 'Death to America! Death to Israel!'23 After 9/11, US president George W. Bush branded Iran (along with North Korea and Iraq) the 'axis of evil', so in protest millions of Iranians rallied and chanted 'Death to America' as they celebrated the twenty-third anniversary of the Islamic Revolution and burned the US flag. ${ }^{24}$ In 2002, during the hajj, in spite of the Saudi ban on political demonstrations, the Iranians in the Iranian complex chanted 'Death to Israel, Death to America'. ${ }^{25}$

In addition to these instances of negative information, whenever there is news of home-grown terrorists people worldwide tend to get more concerned. Academic Muqtadar Khan observed that two images govern Muslims' minds: 'America the democracy' and 'America the colonial power'. The Muslims whose framework is 'America the democracy' form the majority, who are typically peaceful. But adherents to 'America the colonial power' are 'Muslim isolationists' (otherwise referred to as extremists), who argue that Muslims 
must strive to revive the institution of the Khilafah (caliphate), which will take care of all Muslim problems. ${ }^{26}$

\section{Home-grown extremists}

It is not generally known that Muslim extremists are in the minority worldwide; the exploits of a few extremists have been widely publicised in a climate of extreme fear. For example, in 2004-5 Masaoud Ahmed Khan, Seifullah Chapman, Hamad Abdur Raheem and others of the Virginia Jihad Network were convicted for, among other things, conspiring to provide assistance to Lashkar-e-Taiba (a jihadist group based in Pakistan) in the aftermath of the 9/11 attacks. In 2009, US citizens Ehsanul Islam Sadequee and Syed Haris Ahmed were charged with plotting attacks, and both were jailed on terrorismrelated charges. In October 2009 two men from the Chicago area, David Coleman Headley and Tahawwur Hussain Rana, confessed to plotting an attack on a Danish newspaper. Headley also confessed to helping Lashkare-Taiba plan its 2008 Mumbai attacks. ${ }^{27}$ In December 2009 five Virginian youths, Waqir Hussein Khan, Ramy Zamzam, Umar Farooq, Ahmed Abdul Mini and Aman Hasan Yamer, aged 18-24, were arrested in Pakistan for allegedly seeking jihad training. The men, who denied the charges, were tried in Pakistan for planning terrorist attacks in the region, ${ }^{28}$ and in June 2010 were sentenced to ten years imprisonment. ${ }^{29}$ In November 2009, Major Nidal Hasan, a gunman from Fort Hood, Texas of Palestinian background, allegedly killed thirteen people. And on 25 December 2009, the 23-year-old Nigerian Abdulmutallab allegedly attempted to blow up a Detroit-bound Northwest Airlines flight with explosives tucked in his underwear. These incidents show that a small minority of Muslims are a threat to all communities - both Muslim and non-Muslim. In May 2010, Connecticut resident Faisal Shahzad confessed to an attempted Times Square car bombing. ${ }^{30}$ In January that year, a 61-page report, Anti-Terror Lessons of Muslim-Americans, by scholars at Duke University and the University of North Carolina at Chapel Hill, found that since the 11 September 2001 attacks, 139 American Muslims had been accused of planning or carrying out violent attacks motivated by extremism. However, the scholars thought, with a total American Muslim population of 2.5 million, the number of Islamic radicals was very low. ${ }^{31}$ Arguably, though, if their plots had been carried out successfully the scale of disaster would have been horrendous.

\section{The USA Patriot Act}

There is no doubt that many of the foregoing news items concerning the Islamic world have been disturbing. So it is not surprising that soon after the 9/11 terrorist attacks the USA Patriot Act was signed into law. It allows law 
enforcement agencies to use surveillance, and to search and deport people suspected of terrorism-related acts. Research has found that the lives of Muslims (and Arabs) in America have become exceedingly difficult because of the Patriot Act. ${ }^{32}$ As Jane Smith said:

The USA Patriot Act (Providing Appropriate Tools Required to Intercept and Obstruct Terrorism) Act of October 2001 effectively took away all legal protection of the liberty of American Muslims and Arabs. Numerous civil rights agencies have protested this act and worked to have it lifted, as yet to no avail.

The US government has been vigilant in monitoring NGOs, civic, charitable and religious organizations that might be suspected in some way of harboring terrorism. The assets of some have been frozen. This has served to deprive US Muslims of one of the most important ways in which they can fulfill the obligation of paying zakat, through support of charities that give to the poor, widows and orphans. ${ }^{33}$

John Esposito observed that in the five years after 9/11 the Bush administration held 6,472 persons under 'terrorist' or 'anti-terrorist' programmes. Some of those alleged to be terrorists were not charged but were found to be involved in other minor offences such as violation of disability insurance law, failure to file a tax return, or for providing false statements. By 2006 the vast majority had been released without receiving any prison term, though the zeal (which some would claim to be excessive) of the Bush government had certainly generated fear in the wider society. ${ }^{34}$ Smith observed that, since former US President George W. Bush won the first (and only) Muslim bloc vote because of his promise to protect Muslim civil rights, he should have been the one to preside over the abandonment of the laws that infringed the rights of Muslims and Arabs. Instead, some Arabs and Muslims were subjected to humiliation, deportation and in some cases illegal forms of torture during his presidency. ${ }^{35}$

\section{Islamophobia}

As discussed in the introduction, many Muslims faced repercussions after the 9/11 Twin Towers attacks. According to the Arab American AntiDiscrimination Committee, there were more than 7,000 violent incidents targeting Arab Americans or Muslims in the first nine weeks following the attacks. For example, businesses were vandalised and children were the targets of hate slurs in school. ${ }^{36}$ Yasser Ahmed, manager of an Arab-owned candy and grocery store on Broadway in upper Manhattan, New York, said about ten people came to his store and shouted, 'You guys did it!' In Dearborn, Michigan, where nearly one out of every three residents is Arab American, Osama Siblani, the publisher of the Arab American News, said he and his colleagues received several hostile phone calls, including a death threat. ${ }^{37}$ In 
other states, such as California, Illinois, Louisiana, Massachusetts, Texas and Virginia, there were reports of arson attacks at Islamic institutions, personal attacks, pig's blood thrown in mosques and the police profiling men in Middle Eastern-style head coverings, including non-Muslims such as Sikhs. ${ }^{38}$ Privately, an informant told me that his brother was killed in the Twin Towers attacks, and soon after 9/11 his sister's house in New York was vandalised. In Boston, a Pakistani American family said that people stopped going to their restaurant after 9/11. Eventually, their business failed, and they closed their restaurant.

Not only Muslims were persecuted after 9/11: many Sikhs were vilified by members of the wider society because of their visibility (their beard and turban). For example, soon after the September 11th terrorist attacks a man beat a Sikh motel owner in SeaTac, Washington with a cane and told him to 'go to Allah'. Another man punched a Sikh cab driver and pulled out part of his beard. In Arizona, a man shot and killed a Sikh gas station owner and later shouted, 'I stand for America all the way. ${ }^{39}$ In suburban Cleveland, bottles filled with petrol were thrown through the windows of a Sikh temple and flames poured out. There were also incidents where Sikhs were yelled at as 'terrorists'. Many Sikhs (and Arabs and Muslims) were stopped and searched in public places by law enforcement agents. ${ }^{40}$

On a brighter note, since the 9/11 tragedy, many Muslims and non-Muslims have engaged in inter-faith dialogues and attempted to establish social cohesion in American society. Yet widespread discomfort about the presence of Muslims in America remains. In the conventional American media representation of Muslims, many prominent American Christian evangelical leaders have portrayed both Prophet Muhammad (PBUH) and Islam generally in a derogatory manner; for example, one described 'Muhammad as a wild-eyed fanatic and a killer, a terrorist and a demon-possessed pedophile, and Islam as an evil religion'. ${ }^{41}$ As Smith observed, the

Prophet of Islam serves as a model for Muslim belief and behavior, and for Muslims such images are deeply humiliating, as have been many of the cartoons and other depictions of Arabs and Muslims throughout the twentieth and early twenty-first centuries. $^{42}$

Smith comments that before 9/11 Arabs and Muslims were portrayed as 'fools and knaves to oil-rich sheikhs with beards and huge bellies (with harem girls in the background)', and now (after 9/11) these images are converted to 'machine-gun-toting terrorists and suicide bombers'. ${ }^{43}$ A participant of this study, Ismat (female, 16, overseas born of Bangladeshi background, identity: Muslim) observed:

I feel like just in cartoons or [TV] shows every time you watch, you see a Middle Eastern person, you automatically think, 'Okay, terrorist'. That's how [the media 
have] shaped cartoons to turn out to be, it's just your whole idea changes. (Ismat, interview, New York, November 2009)

In December 2002, a cartoon by the cartoonist Doug Marlette was briefly posted on the Tallahassee Democrat's website showing a caricature of Prophet Muhammad (PBUH) driving a nuclear bomb-laden truck similar to that used by Timothy McVeigh in the 1995 Oklahoma City bombing. Its caption ran 'What would Mohammed drive?'. It offended many Muslims and the Florida office of the CAIR called for an apology from the newspaper. The Democrat declined to apologise because the cartoon was not published in its print edition. ${ }^{44}$

Notwithstanding this potential stigma, many Muslims (like other immigrants) are choosing to migrate to America in the hope of a better life and more opportunities. Arguably, the United States is benefiting from this influx but there are sections of the wider society that resist accepting Muslims. For example, in 2010 there was a resurgence of anti-Muslim attitudes when Muslims planned to build a community centre in lower Manhattan near the former site of the World Trade Center.

\section{Park51 Islamic Center}

In 2010 Imam Feisal Abdul Rauf proposed the building of a multi-storey Muslim cultural centre, the Park51 Islamic Center, two blocks away from Ground Zero in New York. It was to include a mosque, sport facilities, a theatre and restaurant and would be open to the public to show that Muslims are full community members. Muslim leaders said that it would be modelled on the YMCA and Jewish Community Center in Manhattan. The centre also planned to include a memorial to victims of the attack on the Twin Towers. ${ }^{45}$ The construction of the centre, a $\$ 100$ million project to be built on private property, was approved by city officials. ${ }^{46}$ On 3 August 2010, New York City's Landmarks Preservation Commission unanimously approved the plans, and President Obama welcomed it because it also aimed to promote religious tolerance. 'This is America', Obama said, 'and our commitment to religious freedom must be unshakeable. The principle that people of all faiths are welcome in this country, and will not be treated differently by their government, is essential to who we are. ${ }^{47}$ Later, at a Friday iftar dinner at the White House to mark Ramadan, Obama said Muslims 'have the same right to practise their religion as anyone else in this country', including by building a mosque in lower Manhattan. ${ }^{48}$ The New York mayor, Michael Bloomberg, a Jewish Republican turned independent, also defended the constitutional right of all religious groups who own private property to build a religious institution. ${ }^{49}$ And the CAIR welcomed Obama's 'strong support for Muslim religious rights'. ${ }^{50}$ 
However, conservative politicians (mostly Republicans but also some Democrats) and some families affected by the $9 / 11$ attacks were against this plan. They believed that it would be a painful reminder of the victims who died in the 9/11 terrorist attacks. Also a CNN/Opinion Research poll in August 2010 showed that 68 per cent of Americans opposed the Islamic centre plans, while only 29 per cent favoured them. ${ }^{51}$ In another poll, conducted by the New York Times, two-thirds of New York City residents wanted the project to be relocated to a less controversial site farther away from Ground Zero, including those who said they favoured it being built. ${ }^{52}$

Apparently, the opponents of Park51 failed to realise that many Muslims had worked in the Twin Towers, with the presence of a musalla in the Twin Tower buildings being clear evidence of this. Nearly 3,000 people were killed when al-Qaeda hijackers crashed commercial airlines into the Twin Towers, the Pentagon outside Washington, and a Pennsylvania field. The number of Muslim casualties at the World Trade Center was about 358. ${ }^{53}$ One of these was Salman Hamdani, of Pakistani heritage, aged twenty-three. Hamdani was a research assistant at the Rockefeller University in Manhattan. He was also a trained paramedic and a member of the New York Police Department's cadet program; so when he saw the Twin Towers in flames, he headed downtown to help in the rescue effort. He died in the rescue mission. ${ }^{54}$

As discussed, the opponents of Park51 still believed that only non-Muslim (mainstream) Americans were casualties of the 9/11 tragedy. For example, Sarah Palin, the 2008 Republican vice-presidential nominee, has urged 'peaceseeking Muslims' to reject the centre, branding it an 'unnecessary provocation'. ${ }^{55}$ US Senator John Cornyn, a Texas Republican, commented, 'But I do think it's unwise ... to build a mosque at the site where 3,000 Americans lost their lives as a result of a terrorist attack. ${ }^{56}$ New York Republican Congressman Peter King said the Muslim community was 'abusing' its rights and 'needlessly offending' many people. 'It is insensitive and uncaring for the Muslim community to build a mosque in the shadow of Ground Zero ... Unfortunately, the president caved in to political correctness. ${ }^{57}$ And Mark Williams, chairman and spokesman for the Tea Party, said, 'The mosque would be for the worship of the terrorists' monkey god. ${ }^{58}$ Another fierce opponent of the Park51 mosque was the Florida evangelical pastor Bill Keller. Keller hosted a popular televangelism programme in Florida until 2007, when CBS forced him off the air for declaring, 'Islam is a 1,400-year-old lie from hell, and that history clearly shows Muhammad was a murdering paedophile. ${ }^{59} \mathrm{On}$ 5 September 2010 Keller preached a sermon attended by about forty people at the New York Marriott Downtown, overlooking Ground Zero, and said, 'Islam is not and has never been a religion of peace ... How could you build bridges with people who ask their Muslim brothers to fly a plane into the twin towers and kill thousands of innocent people?' He also said that all the people who were behind the proposed mosque will 'burn in hell'. ${ }^{60}$ 


\section{The Quran-burning incident}

Opposition to the plan to build the Park51 Islamic Center has continued. In 2010 Terry Jones, pastor of a small Florida church, vowed to mark the 9/11 anniversary and honour the deaths of the people killed in the al-Qaeda attack by burning a copy of the Quran. The day was also set to coincide with the festivities for Eid-ul-Fitr. Pastor Jones said the Quran burning was intended 'to remember those who were brutally murdered on September 11', and to send a warning 'to the radical element of Islam'. This made worldwide news and Anders Fogh Rasmussen, the NATO secretary general, warned that it would be a security risk for the troops present in Afghanistan. ${ }^{61}$ Pastor Jones temporarily suspended the idea, but on 20 March 2011 he presided over the burning of a copy of the Quran at his Dove World Outreach Center in Gainesville, Florida.

The burning of the Quran sparked deadly attacks in Afghanistan. On Friday 1 April 2011 in Mazar-e-Sharif, northern Afghanistan's largest city, thousands of protesters came out of the large Blue Mosque and marched toward the United Nations mission a mile away. The angry mob entered the compound chanting 'Death to America', burned the US flag and killed seven UN workers. Demonstrations also spread throughout the country. ${ }^{62}$

\section{Other related incidents}

During the period when Park51 was being debated, a few other incidents of religious intolerance occurred. For example, in August 2010 in New York City, a Muslim cab driver of Bangladeshi heritage, Ahmed H. Sharif, aged forty-three, was carrying a young American passenger, Michael Enright, aged twenty-one. Enright had a casual conversation with the cab driver, asking him if he was a Muslim and greeting him by saying 'Assalamu alaikum' (peace be upon you), and asking Sharif how his celebration of Ramadan was going. Then Enright suddenly attacked Sharif with a knife and slashed him in his face, arm and hands, which later required twenty-eight stitches. Sharif said the attack had shattered his American dream. 'I feel very bad. I have been here more than twenty-five years. I have been driving a taxi more than fifteen years. All my four kids were born here. I never felt this hopeless and insecure before.' A taxi drivers' association blamed the attack on prejudice towards plans for the Islamic centre. ${ }^{63}$ Nevertheless, in August 2010, reporting on the Park51 issue, the Time reporter Bobby Ghosh remarked:

Islamophobia in the US doesn't approach levels seen in other countries where Muslims are a minority: there's no American equivalent of France's ban on the burqa or Switzerland's new law against building minarets. Polls have shown that most Muslims feel safer and freer in the US than anywhere else in the Western world. ${ }^{64}$ 
Ghosh informed readers that the first wave of anti-Muslim rhetoric after 9/11 came from leading Christian figures such as Pat Robertson, Jerry Falwell, Saxby Chambliss and Franklin Graham. For example, Robertson and Falwell doubted whether Islam was a religion and branded Prophet Muhammad (PBUH) 'a robber, brigand and terrorist'. ${ }^{65}$ As I read the Time report, I wondered whether Ghosh's observation that Islamophobia in America was more subdued than in France and Switzerland ${ }^{66}$ was correct. It is true that Switzerland has outlawed the building of minarets, and France has banned the wearing of the niqab in public places, but in 2009 the Muslim population in Switzerland was about 5 per cent of the total, ${ }^{67}$ and in April 2011 the Muslim population in France was estimated at about 10 per cent of the total. ${ }^{68}$ The fact that in 2011 the Muslim population in America was only 0.88 per cent ${ }^{69}$ suggests that either Europe has been a more favoured settlement destination of Muslim migrants or European immigration policies have been more accepting of Muslim migration. In any event, it seems fair to say that the vociferous resistance to the Park51 Islamic Center in America is unhelpful for the social cohesion of Muslims and non-Muslims in American society. Figure 1.1 shows the intensity of anti-Muslim rage in America and Europe.

With this backdrop of events impacting on Muslims in the United States, I turn to examine the identity of young American Muslims. In the next section, I explore the concept of identity and provide some anecdotes to illustrate how various factors can shape identity.

\section{Examining the concept of 'identity'}

Identity is the condition of being oneself (and not another). Arguably it is a process that is fluid and is shaped according to circumstances and opportunities. Identity may depend on the family one is born into, the culture and religion one belongs to, one's community and one's life experiences. In 2001 a team of sociologists identified ten 'identity markers' that people use to claim or attribute identity: place of birth, ancestry, place of residence, length of residence, upbringing and education, name, accent, physical appearance, dress and commitment to place. ${ }^{70}$ Elsewhere, Fiona Douglas found identity to be a complex and fascinating phenomenon. 'At a basic level, identity is about who we are, and who and what we identify with. However, identity is also about who we want to be, and how we wish to be seen by others. ${ }^{71}$ In other words, Douglas suggested that identity can go beyond nationality and place of birth. It can be 'a state of mind'. ${ }^{72}$ Identity is both individual and group oriented. Richard Jenkins stated:

- 'Identity' denotes the ways in which individuals and collectivities are distinguished in their relations with other individuals and collectivities.

- 'Identification' is the systematic establishment and signification, between 


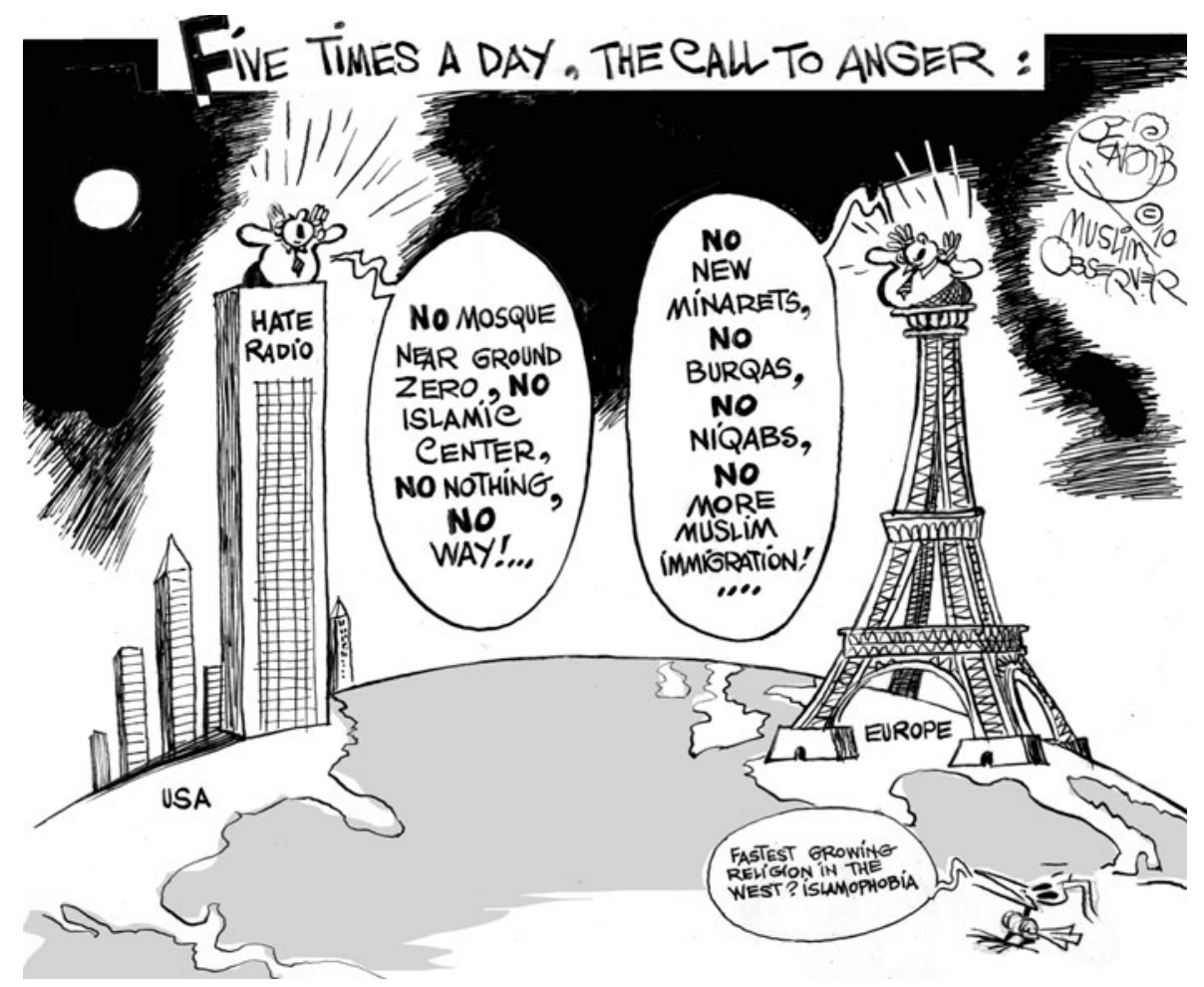

Figure 1.1 Five times a day, the call to anger.

From Muslim Observer, 2 September 2010

(C) Khalil Bendib, all rights reserved.

individuals, between collectivities, and between individuals and collectivities, of relationships of similarity and difference.

- Taken - as they can only be - together, similarity and difference are the dynamic principles of identification, and are at the heart of the human world. ${ }^{73}$

Jenkins observed that group identification involves the 'centrality of power, and therefore politics, in identity maintenance and change. Asserting, defending, imposing and resisting collective identification are all definitely political.' Jenkins also suggested that external factors play a significant role in group or collective identity. ${ }^{74}$ Identity recognises similarity, or shared belonging, and the differences that form the rhetoric of 'us' and 'them'. In other words it creates an 'ingroup' against an 'outgroup'. Paul Gilroy commented:

Identity is always particular, as much about difference as about shared belonging ... Identity can help us to comprehend the formation of the fateful pronoun 'we' and to reckon with the patterns of inclusion and exclusion that it cannot help but to create. 
This may be one of the most troubling aspects of all: the fact that the formation of every 'we' must leave out or exclude a 'they,' that identities depend on the marking of difference. ${ }^{75}$

Gilroy finds the term 'identity' problematic because it creates division. Peter Burke and Jan Stets believe that social identity is based on membership in a group or category that gives one a shared feeling with others in the group. When one receives recognition, approval and acceptance from a group then one is more likely to feel a part of that group. Thus, 'one is verified as a member by being like the other members. Being verified in terms of social identity reinforces group-nongroup distinctions, thus maintaining boundaries and supporting the continued differentiations and cleavages in the social structure. ${ }^{76}$

For example, when a Muslim woman looks Muslim by virtue of her Islamic attire, regardless of her ethnic background, she is identifying with the broader Muslim ummah and inadvertently distancing herself from non-Muslims. One of the participants in this study, Shahnaz (female, 29, overseas born, Bangladeshi background), identified herself as 'Muslim only'. By profession, Shahnaz is a scientist. She also spends her after-work time as a social worker. Shahnaz tells the story of how she endorsed her Islamic identity by wearing the hijab:

Hijab is a long story of mine. I was so anti-hijab you cannot imagine. There was a girl in our office who converted to Islam and she called me one day and she said, 'I want to talk to you about this Islam, I am having difficulty and I know you don't do it too, but I want to talk to you.' So we were looking through the Quran and she said, 'Look, this is where it is saying to pull up your veils over your clothes.' And I said, 'Well, it doesn't say that you cover your head ... the Quran said to pull it over your bosom. ${ }^{77}$

Later, I met this Egyptian woman and so we were sitting and I was reading the Quran in English and I was explaining to her and the hijab question came [up] and she was saying, you know, 'When I started hijab, I lost so many of my Muslim friends.' She lost Muslim friends when she started wearing hijab in Egypt. So, one day I thought, 'Should I take that risk?' If I wore the hijab then I might also lose some friends. It changed the whole profile of me. (Shahnaz, interview, Maryland, 2010)

Shahnaz observed that at work before she wore the hijab she was widely accepted by her colleagues. After she started wearing it she noticed the difference:

It did, it changed so much. I guess one of the guys at work said, 'I miss your hair.' And I said, 'That is the purpose, you know that I wear it.' But anyway, it has made a big difference. Before hijab I was one of them, but now with the hijab, I am an outsider. 
Everything, everything, everything, the whole attitude, it's just like you are different, you know. It's hard, it's very difficult, it's very frustrating, you know. They don't take the value of you. I just tell Allah, 'I place you in front of them and me, I can't hide my battle because I am just human and so you may fight my battle.'

This case hardly suggests discrimination because Shahnaz was still continuing to do her job. Apparently Shahnaz's colleagues thought she chose to separate herself from them with her religious visibility.

Stuart Hall observed that identity is constructed through internal homogeneity, and thereby it forms a closure. ${ }^{78}$ Identity constructs internal unity and thus it brings to the fore power and exclusion, and power play and exclusion are only possible through the overdetermined process of 'closure'. ${ }^{79}$ Hall also noted the transitional nature of identity: 'Identity is actually formed through unconscious processes over time, rather than being innate in consciousness at birth. There is always something "imaginary" or fantasized about its unity. It always remains incomplete, is always "in process", always "being formed". 80

Academics such as Peter Burke, Jan Stets and Sheldon Stryker have observed that emotion can play an important role in the formation of one's identity. Emotions have an influence on the formation of social networks; people with 'shared affective meanings' are more likely to enter into and maintain a social relationship. And people with intense positive emotions towards a network or group are likely to identify with it. ${ }^{81}$ For example, a Muslim may identify with another Muslim or an Islamic organisation. But with intense negative emotions, they will distance themselves from that network or group. For example, if a Muslim turns out to be radical, his moderate Muslim friend may maintain a social distance from him. Similarly, when individuals are highly committed to a role identity, such as the parent identity, a failure to meet the role expectations may result in a greater negative emotional response. ${ }^{82}$ For example, if a Muslim father, without prior consultation with his daughter, pulls her out from a public school and enrols her in an Islamic school, and if he is adamant that his daughter should assume an Islamic identity and insists that she should wear the hijab, then the daughter who previously felt positively about her identity may feel quite the contrary and reject her Islamic identity. (I discuss this further in Chapter 3, in the 'Americanness' section.)

Henri Tajfel pointed out that individuals can more readily assert their belonging to or membership of a certain group when they feel accepted in that group. Social identity theory also suggests that individuals are more likely to identify with a certain group if that identification is associated with enhanced self-esteem..$^{83}$ My study on young British Muslim identity found that people's self-esteem is enhanced if they get enough support from their respective communities, the way they are brought up in their respective homes, the values and norms they learn from their educational and religious institutions, their 
interaction and communication with wider society and recognition from that wider society. ${ }^{84}$ Therefore, two factors - acceptance and recognition - play important roles in the formation of one's identity. Richard Jenkins provided this thumbnail sketch of the complexities of social identity:

Society is structured categorically, and organised by inequalities of power and resources. It is in the translation of social categories into meaningful reference groups that 'social structure' influences or produces individual behaviour. Social identity theory focuses on how categories become groups, with the emphasis on inter-group processes.

Individuals, in using stereotypical categories to define themselves, thus bring into being human collective life. Individuals will self-categorise themselves differently and the contingencies with which they are faced..$^{85}$

Steph Lawler observed that identities are socially produced, and are uniting as well as oppositional, such as man-woman, black-white. Identities can also involve tension such as a person having two roles, for example a woman being a mother and a worker. ${ }^{86}$ Dual or multiple identities can often compete with each other, so that 'the approval and disapproval of certain kinds of identity draws lines between "us" and "them"' ${ }^{87}$ For example, a visibly bearded Muslim, Rasheed (male, 19, US born, Pakistani background), said, 'Two years ago, I used to say "I'm Muslim", but now first and foremost of course I'm Muslim, but citizenship-wise I'm an American. I just have too strong ties to America.' Rasheed is visibly Muslim and is involved with Muslim organisations, but he appreciates American democracy, putting it like this:

I mean it's freedom of speech, freedom of religion. The fact is that, you know, the people are the rulers. Government is representative of the people's ideas, right? I'm one of the subscribers to that, that the government should be afraid of the people, that is more along with my philosophies and it fits very well with America. And the people who have come here, on average, tend to be very accepting of others. (Rasheed, interview, Massachusetts, November 2009)

Rasheed connected his American spirit with his childhood memories when he said:

Those of us who grew up in the '90s, we inherited the American spirit through all the cartoons that we watched, the media we got ... there was a strong push for the pride in the America that we have.

Rasheed did not connect himself with his Pakistani ethnicity because he had been to Pakistan only once so far, and said, 'I have a very limited vocabulary 
in Urdu'. When I asked him about mushairas (Urdu poetic symposiums), Rasheed replied, 'Unfortunately that's a culture inaccessible to me because I can't really appreciate the language too well ... Yeah, most of the high Urdu is beyond me.' Like any other young American, Rasheed liked music: 'I used to be into heavy rock. I've now mellowed out a little bit, I'm now into some softer rock. And I've started enjoying some indie music.' When I asked him whether in his childhood he celebrated Halloween and Thanksgiving, Rasheed replied:

Not really Halloween. Halloween my parents were very strict on, and for Thanksgiving my family was more of a hub of our friends in the area. We would have a big celebration around Thanksgiving time and had halal turkey, halal rabbit, halal duck, halal quail.

Rasheed was a practising Muslim, but culturally he was more American. But when I asked him, 'What would be "un-American"?', he promptly replied, 'The Patriot Act restricts your freedom, it allows people to have more power over you, so it is morally or ethically reprehensible. And so that is in many ways "un-American".' Rasheed was also critical of some events at his university campus (perhaps his Islamic identity prompted him to share this view):

Two years ago there was a national campaign by somebody to have Islamo-fascism Awareness Week, essentially as a response to Islam Awareness Week, which takes places once a year all over the nation. And so this [Islamo-fascism Awareness Week] is essentially, in our perspective, an attempt to slander in a way and incite anger against Islam and Muslims across the globe, and this is an event banned at many campuses. It was organised by some anti-Islam group trying to provoke anger.

'Islamo-fascism Awareness Week' was observed on 114 college and university campuses in the week of 22-6 October 2007. The organisers aimed to protest against the violent oppression of women in Islam and advertised in campus newspapers and circulated pamphlets on that issue. They also showed documentaries, such as Obsession and Suicide Killers, and organised panel discussions and talks by controversial speakers such as former senator and Republican presidential nomination candidate Rick Santorum, Ann Coulter, Robert Spencer, Nonie Darwish, Wafa Sultan, Michael Medved, Dennis Prager and Daniel Pipes. ${ }^{88}$ Islamo-fascism Week was also mentioned by other participants of this study, who were distressed by the Islamophobic attitude of this group. I was told by a student in San Francisco (when I attended a conference there in 2009) that during Islamo-fascism Week some students on their campus held up the Hamas flag and threw shoes at it. The Hamas flag is green in colour and has the shahada (first pillar of Islam) written on it. As Rasheed said, it was done to provoke a reaction from Muslims. 
The point is that identity involves emotions and tensions, particularly when the 'self' confronts a crisis, which may polarise identities. In this case Rasheed's Islamic identity prompted him to speak on the issue. With regard to the flexible nature of identity, sociologist Avtar Brah, in the British context, observed:

Identity is not an already given thing but rather it is a process. It is not something fixed that we carry around with ourselves like a piece of luggage. Rather, it is constituted and changes with changing contexts. It is articulated and expressed through identifications within and across different discourses. To have a sense of being, say, Muslim is therefore different when confronted with non-Muslims than with friends and family. This sense of self will vary depending on whether the non-Muslims are friendly or hostile. ${ }^{89}$

Brah acknowledged that there could be cultural conflict within the Muslim community, and that that conflict might not have an impact on one's identity in the same manner when the (majority) non-Muslims are antagonistic to (minority) Muslims. That is, a Muslim's identity will shape up according to the friendly or hostile attitude of non-Muslims towards him or her. Regarding 'identity' as 'a work in progress', Brah observed that, when non-Muslims or mainstream westerners treat Muslims with hostility or difference (as 'the other'), Muslims can become anti-western, or choose to identify themselves with the broader ummah..$^{90}$ Brah said that the discourses and practices of Islamophobia can lead to the construction of one's Islamic identifications and prompt Muslims to connect to conflicts affecting Muslims globally, such as in Iraq, Chechnya and Kashmir. Thus Islamophobia increases a sense of grievance on behalf of all Muslims. It has also been observed that young Muslims (residing as a minority in the non-Muslim majority countries) can construct their exclusive 'Muslim' identity based on foreign policy, social exclusion and Islamophobia. ${ }^{91}$

In my previous work on Australian and British Muslim identity, I pointed out that most of the participants with an exclusive Muslim identity, or a 'Muslim first' identity, were peaceful and law-abiding citizens. Similarly, in my study of 379 American Muslims, thirty-six (eighteen male and eighteen female) participants said that they were 'only Muslim', fourteen (seven male and seven female) said that they were 'Muslim American', with the emphasis on 'Muslim first', and eleven (six male and five female) said that they were American Muslims, with the emphasis on Muslim being secondary. (The remaining 318 participants' identities are discussed in Chapter 3.) In its survey of 1,033 American Muslims in 2011, the Pew Research Center found 49 per cent of its participants identified themselves first as a Muslim, compared with 26 per cent who thought of themselves first as American. ${ }^{92}$ I have argued consistently that having an exclusive Islamic identity is not harmful as long as the person is peaceful. I have also emphasised that Muslims' peaceful discussions, rallies or demonstrations in the western world should be encouraged - as long 
as their allegiances lie also with the host country. ${ }^{93}$ In the face of current geopolitical events, nevertheless, I have proposed biculturalism (discussed in the Introduction and Chapters 2 and 3) so that young Muslims can be given room to express their identities.

\section{The research methodology}

\section{Rationale for choosing six states}

The rationale for choosing Massachusetts, New York, Virginia, Maryland, Florida and Michigan consecutively for my study was as follows: I conducted research in Massachusetts because I was based in Boston as a visiting fellow at Harvard University, and I thought it was important to include the voices of young Muslims in the state in which I was residing. The Twin Towers terrorist attacks took place in New York, so I thought it was essential to examine the views of Muslims who had lived through this ordeal. Virginia and Maryland are bordered by Washington, DC, so I thought I should hear from the young Muslims of these two states to see if they felt more connected than other Muslims to America. People living in close proximity to the White House might feel special. My research interest in Florida was based on a request from some local Muslims in that state. I called an Islamic organisation in Florida and they were very impressed with my research topic and requested that I incorporate their state in my study. Finally, Michigan has the largest and the oldest Muslim and Arab population in the United States. ${ }^{94}$ I visited Detroit in 2004 and was impressed by the Arab setting of Dearborn. For example, the names of some shops and medical centres were written in Arabic, which reminded me of my stay in the Middle East. So I was keen to obtain the views of young Muslims of this state and find out how they defined their identity or sense of belonging.

\section{Recruitment techniques}

I applied various techniques to gather participants for this study. First, I addressed large Muslim audiences at events such as Ramadan/fasting (iftar) in different venues, and explained to them the nature of my project. I told them that I was looking for participants for this study. Secondly, I contacted various principals of Islamic and public and charter schools, colleges and university coordinators, directors of youth centres, imams, and leaders of Muslim organisations through telephone calls and emails. I explained to them the nature of my study. If they showed interest in participating in the survey, I emailed them the relevant documents (recruitment/request letter, questionnaires, parents' and students' information sheets, and consent forms). Finally, at some institutions I made PowerPoint presentations about my previous study, Muslims in Australia, hoping that the potential participants would respect me as a 
researcher and want to support my study of the identity of young American Muslims. Many audience members later told me that they were pleased to know about the presence and contribution of Muslims in Australia and a few said that they had not known that there were any Muslims in Australia!

\section{Approach}

Participation in this study was voluntary. All the younger participants (aged fifteen to seventeen) submitted their parents' signed consent forms and signed their own consent forms. In most cases, they wanted to know more about my study and how the information would be used. When I told them I intended to write a book (but that they would remain anonymous in my work), they became more interested in being interviewed. I also told them that this would be my third book, the previous two books having been written on Muslims in Australia and Britain. Participants who were eighteen years old and over also signed consent forms and voluntarily participated in the study. Many participants commented, 'You are doing it for a good cause.' Some (particularly the minors) desired that their names be mentioned in my work. However, I told them that for ethical reasons I had to maintain confidentiality and give them fictitious names.

As an insider (which I have discussed in the Introduction to this book), I felt privileged to be conducting this research and to be welcomed in the various Muslim communities. My affiliation with Harvard University was also respected by the participants of this study. As an outsider (a researcher), I tried to overlook my bias and be objective about the issues discussed in this book. In this study (and my previous research) I was mindful of the importance of integration, following Ali Kettani's observation in assuming that this does not entail immigrants abandoning their identities. I believe that immigrants should retain their ethnic and religious identity while adopting aspects of the host society's culture. ${ }^{95}$ To sum up, my role as researcher was a dual one: on the one hand, as a Muslim studying Muslims I was an insider; on the other hand, my theoretical and critical interest as a researcher positioned me as an outsider.

\section{Why target young participants?}

I decided to study the identity of young Muslims (fifteen to thirty years old) for three reasons. First, this age group is growing up in a period that is quite different from that of previous generations. Secondly, it comprises mainly secondgeneration Muslims whose identity is wavering. They are placed between the diaspora and the host country setting. The first-generation immigrants may have desired that one day they would return 'home' (to their country of origin). I thought it would be fascinating to examine the views of the second generation about their 'identity and belonging'. Finally, from a security point of view, it is 
important to engage young Muslims. Evidence from the UK and USA suggests that this age group is susceptible to more radical versions of political Islam. ${ }^{96}$

\section{Qualitative method}

I have employed the grounded theory method ${ }^{97}$ Grounded theory is a type of qualitative method. It is a non-statistical methodological approach that is about 'letting the data speak' and not imposing pre-formed hypotheses. The goal of this research was to gain a better understanding of the participants through their life stories, hopes and aspirations. Most importantly, it was designed to allow respondents to speak about issues important to them. In conjunction with this, I have employed the constructivist method of interpretation. ${ }^{98}$ Constructivism emphasises the researcher's unique ability to make their own meaning out of information (interviews) rather than measure causal relations according to preconceived variables. The main data gathering method was face to face via semi-structured interview questions and a form of narrative analysis, whereby interview responses were regarded as a story about each interviewee's life. Of course each narrative contains unique elements, but some patterns could be detected in the participants' lives that enabled the identification of themes and low-order generalisations. I realise that my interpretation of the data could be biased. But by reporting on patterns and frequencies and by displaying my analysis of samples of interview responses, I endeavour to demonstrate to the reader that I have dealt with the data in a fair and reasonable manner.

To recruit people for my sample I used snowballing and representative sampling techniques. The snowballing technique involves referrals from initial participants to generate additional participants. Whereas this technique can be effective in building up the number of willing participants, it comes at the risk of producing an unrepresentative sample. To counteract this, I used the representative sample technique of commencing with a diverse set of groups of participants from an entire population of possible participants. For example, I deliberately selected different schools, colleges and youth centres from a wide range of educational institutions in different states. Similarly, I chose Muslim leaders and community workers from different states because they had different personalities and regional views.

The data gathered was framed by the interview questions, which were submitted to the Harvard ethics committee. All interviews were tape recorded. Only five participants wished that their views be written down.

In the interviews, I asked the younger participants (aged fifteen to seventeen) about their lives, including early school memories, number of family members, parents' work status, their own part-time work, identity/national identity, sporting activities, music, entertainment and cultural interests, together with their hopes, ambitions and dreams. There were specific questions on 
- how they felt as an American and as an American Muslim

- what it meant to be 'American' and 'un-American'

- whether all Americans should exercise their right to vote

- whether they would be interested in exercising their voting rights when they turned eighteen

- their opinion of President Barack Hussein Obama

- whether his rise as the first black American president inspired them

- what they thought of the American media

- whether the 9/11 tragedy had impacted on them

- what Muslims should do to achieve social cohesion.

For the participants aged eighteen and over, there were additional questions on voting, Islamic parties, views on shariah law, Muslim dress code in workplaces, Muslims' reaction to the cartoon of Prophet Muhammad (PBUH) cartoon first printed in Denmark, and their views on anti-terrorism laws, the US justice system, the economic system, American banks, US presidents, the US Congress, the US police and the US military. And for the Muslim leaders and other Muslim Americans (aged thirty and over), there were further specific questions on the overall Muslim settlement in America, their own migration story, whether they had noticed any changes in the Muslim community and the wider society, whether young Muslims' issues were being addressed in education, sport and employment, and whether there was enough dialogue between young people and Muslim leaders. I did not have any specific question on Palestine. During the discussions on identity and belonging, the media and President Obama, the 'Palestinian question' was brought up by some participants, of both Palestinian and non-Palestinian background.

\section{Total number of participants}

The number of interviews conducted in Massachusetts, New York, Virginia, Maryland, Florida and Michigan totalled 379. The numbers of institutions that participated in this study are as follows: schools: twelve, youth organisations: four, Muslim organisations: six; mosques: six. Details of the participants are shown in the four tables below.

Table 1.1 shows that participants aged fifteen to thirty constituted 89 per cent of the total: 76 per cent students and 13 per cent non-students. Participants over thirty made up the remaining 11 per cent. Table 1.2 shows a further subdivision of Table 1.1. The 'young adults - students' category comprises participants attending high school, college and university. The non-student category covers those who are not studying: leaders of Muslim organisations, imams, social workers, youth workers, other working people (employed and self-employed), homemakers and those looking for a job.

The religious affiliations of the interviewees were as follows: Sunni: 358, 
Table 1.1 Participants by state and gender

\begin{tabular}{lccccr}
\hline State & $\begin{array}{c}\text { Male } \\
(15-30)\end{array}$ & $\begin{array}{c}\text { Female } \\
(15-30)\end{array}$ & $\begin{array}{c}\text { Male } \\
\text { (over 30) }\end{array}$ & $\begin{array}{c}\text { Female } \\
\text { (over 30) }\end{array}$ & Total \\
\hline Massachusetts & 13 & 11 & 8 & 4 & 36 \\
New York & 28 & 46 & 2 & 4 & 80 \\
Virginia & 7 & 16 & 0 & 3 & 26 \\
Maryland & 15 & 15 & 0 & 5 & 35 \\
Florida & 45 & 44 & 6 & 1 & 96 \\
Michigan & 38 & 60 & 5 & 3 & 106 \\
Total & 146 & 192 & 21 & 20 & 379 \\
\hline
\end{tabular}

Table 1.2 Participants by age and gender

\begin{tabular}{lcccccc}
\hline & Youths $^{\mathrm{a}}$ & $\begin{array}{c}\text { Young adults }^{\mathrm{b}} \\
\text { - students }\end{array}$ & $\begin{array}{c}\text { Young adults } \\
\text { - non-students }\end{array}$ & $\begin{array}{c}\text { Adults } \\
\text { students }\end{array}$ & $\begin{array}{c}\text { Adults } \\
\text { non-students }\end{array}$ & Total \\
\hline Male & 74 & 52 & 20 & 0 & 21 & 167 \\
Female & 114 & 50 & 28 & 1 & 19 & 212 \\
Total & 188 & 102 & 48 & 1 & 40 & 379 \\
\hline
\end{tabular}

a $15-17$ years old

b $18-30$ years old

c Over 30 years old

Shia: 18, NOI: 3. These groups are defined in Chapter 2. The ethnic composition of the interviewees is shown in Table 1.3.

It should be noted that a few participants had hyphenated backgrounds, such as Palestinian-Russian, Pakistani-Indian, Lebanese-Italian, LebaneseEcuadorian, Turkish-Cuban, Egyptian-Filipino and French-Moroccan.

All 379 interviewees participated voluntarily, knowing that the study was about Muslim identity. I respected their identity as 'Muslims' and did not delve into their degree of religious practice. Many respondents were visibly Muslim, particularly those women who wore the hijab (even in state schools and colleges).

\section{Fieldwork challenges}

In order to obtain a representative sampling I had to persist at networking and establishing trust. Sometimes it was frustrating. For example, in Virginia I found an unusual calm in one of the youth centres. The timing of my visit in that state was not the best: it coincided with the arrest of the alleged terrorists the Virginia Five, five Muslim men from Virginia arrested in Pakistan on 9 December 2009. ${ }^{99}$ People may have had doubts about the aim of my research. The sample numbers in Virginia (Table 1.1) reveal that I had less success in recruiting participants in that state. In another state, I was asked by a school 


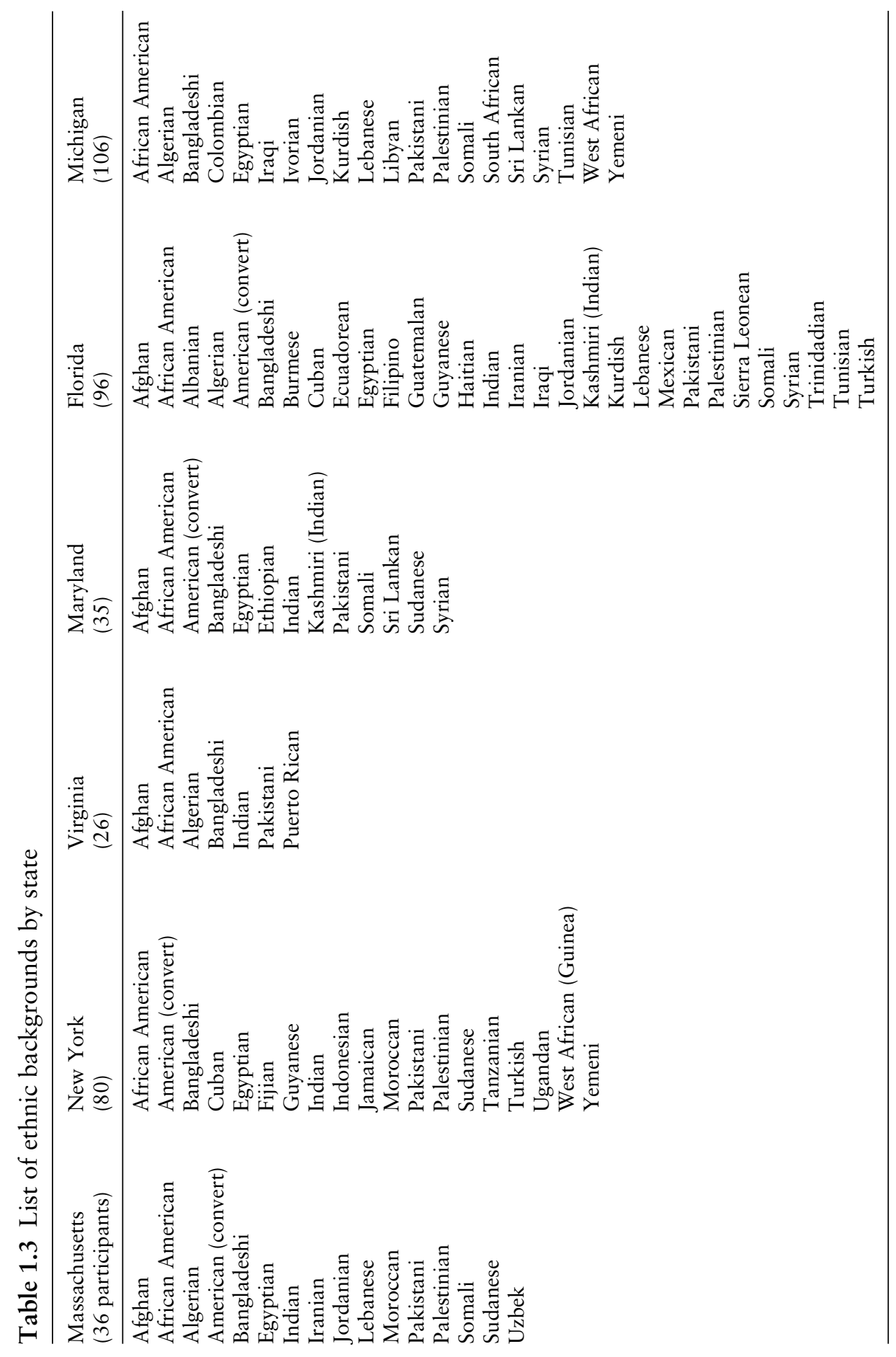


Table 1.4 Participants by ethnic background

\begin{tabular}{lc}
\hline Ethnic background & Number of participants \\
\hline Pakistani & 58 \\
Palestinian & 53 \\
Bangladeshi & 52 \\
Egyptian & 38 \\
Yemeni & 20 \\
African American & 19 \\
Indian & 12 \\
Somali & 12 \\
Afghan & 10 \\
Guyanese & 10 \\
Lebanese & 8 \\
Syrian & 7 \\
Trinidadian & 7 \\
Other & 73 \\
\hline
\end{tabular}

superintendent what benefit the school board would receive from my research. I told the superintendent that if she wished I would give her a summary of my findings which would help them to evaluate the diversity in their schools. The superintendent declined my request, saying that they did not have any issues because Muslims and Arabs have been living in that region for a long time. Finally, in a different state, the Department of Education declined my application/request by saying that their public schools do not engage with any research based on religion. Their letter read: 'The ... district has decided not to participate in your research proposal ... 'An Understanding of the Identity of Muslim Youths and Young Adults in the United States of America'. The district does not collect information on student religious beliefs. ${ }^{100}$

However, most of the educational institutions that participated in this study acknowledged that this was an important inquiry, and such research would enhance the participants' self-esteem because they were acquiring skills in speaking to a person outside their comfort zone (educational institutions).

\section{Notes}

1. See also Jane I. Smith, Islam in America, 2nd edn (New York: Columbia University Press, 2010), pp. 8-22.

2. Seyyed Hossein Nasr, The Heart of Islam: Enduring Values for Humanity (San Francisco: HarperSanFrancisco, 2002), p. 65.

3. Amir Nashid Ali Muhammad, Muslims in America: Seven Centuries of History 1312-2000, 2nd edn (Beltsville, MD: Amana, 2001) pp. 9, 15.

4. Ibid., p. 17. 
5. Gulam M. Haniff, 'The Muslim Community in America: A Brief Profile', Journal of Muslim Minority Affairs 23:2 (2003), pp. 303-11, see pp. 303-4.

6. Arab Americans: An Integral Part of American Society (Dearborn, MI: Arab American National Museum, 2009), p. 16; Abdus Sattar Ghazali, 'The number of mosque attendants increasing rapidly in America', American Muslim Perspective website, 4 August 2001, http://www.amp.ghazali.net/html/mosques_in_us.html, accessed 14 May 2012.

7. Haniff, 'The Muslim Community in America', pp. 303-4.

8. Ibid., pp. 307, 310.

9 Muslim Americans: No Signs of Growth in Alienation or Support for Extremism (Washington, DC: Pew Research Center, 2011), p. 20, http://www.people-press. org/files/legacy-pdf/Muslim-American-Report.pdf, accessed 15 May 2012.

10. According to the US Census Bureau, the total resident population of the United States on 2 September 2011 was 312,119,344: http:/www.census.gov/ population/www/popclockus.html, accessed 2 September 2011.

11. Muslim Americans, p. 16.

12. Ibid., p. 13.

13. Muhammad, Muslims in America, pp. 75-81.

14. Ibid., pp. 75-81.

15. See Nahid Afrose Kabir, Muslims in Australia: Immigration, Race Relations and Cultural History (London: Routledge, 2005), p. 157.

16. Paul M. Barrett, American Islam: The Struggle for the Soul of a Religion (New York: Farrar, Straus and Giroux, 2007), p. 6.

17. Rashid Ahmed, Taliban: The Story of the Afghan Warlords (London: Pan, 2001), p. 94.

18. M. Ruthven, Fundamentalism: The Search for Meaning (Oxford and New York: Oxford University Press), pp. 110-11, 121.

19. 'They, who are with sin, are stoned ... Two adulterers die under Taliban law,' Houston Chronicle, 3 November 1996, p. 28. See also Nahid Afrose Kabir, Young British Muslims: Identity, Culture, Politics and the Media (Edinburgh: Edinburgh University Press, 2010), pp. 180-3.

20. Yvonne Kinsella, 'Outrage at Amina's plight', Daily Mirror, 6 August 2004, p. 5.

21. 'Iran "stoning woman" to get 99 lashes', SBS World News Australia website, http://www.sbs.com.au/news/article/1345357/Iran-stoning-woman-to-get-99lashes, accessed 14 May 2012.

22. 'Nine executed in Iran under Sharia law', Irish Times, 2 August 2007, p. 11.

23. "Ahmadinejad says Israel-Palestinian peace talks "doomed"', World News Australia, SBS One, 4 September 2010, 6.30 p.m.

24. Neil Macfarquhar, 'Iranians chant "Death to America", The Spectator (Hamilton, ON), 12 February 2002, p. D05.

25. Reuters, 'Haj pilgrims denounce Israel and U.S.', 22 February 2002.

26. M. A. Muqtedar Khan, 'Constructing the American Muslim Community', in Yvonne Haddad, Jane Smith and John L. Esposito (eds), Religion and 
Immigration: Christian, Jewish, and Muslim experiences in the United States (Walnut Creek, CA: Altamira Press, 2003), pp. 175-98.

27. Christopher Dickey, 'A thousand points of hate', Newsweek, 1 January 2010, pp. 34-6; see also 'From Pakistan to the world,' Time, 17 May 2010, pp. 18-19.

28. 'From Pakistan to the world'.

29. Waqar Gillani and Sabrina Tavernise, 'Pakistan sentences five Americans in terror case', New York Times website, 24 June 2010, http://www.nytimes.com/ 2010/06/25/world/asia/25pstan.html, accessed 14 May 2012.

30. 'From Pakistan to the world'.

31. David Schanzer, Charles Kurzman and Ebrahim Moosa, Anti-Terror Lessons of Muslim-Americans (Durham, NC: Duke University/University of North Carolina at Chapel Hill, 2010), http://fds.duke.edu/db/attachment/1255, accessed 14 May 2012.

32. Tony Gaskew, Policing American Muslim Communities: A Compendium of Post 9/11 Interviews (Lewiston, NY: Edwin Mellen Press, 2008), pp. 151-72. See also Detroit Arab American Study Team, Citizenship and Crisis: Arab Detroit after 9/11 (New York: Russell Sage Foundation, 2009).

33. Smith, Islam in America, pp. 187-8.

34. John L. Esposito, The Future of Islam (New York: Oxford University Press, 2010), p. 163; see also Louise Cainkar, Homeland Insecurity: The Arab American and Muslim American Experience after 9/11 (New York: Russell Sage Foundation, 2011), p. 128.

35. Smith, Islam in America, p. 186.

36. Talat Hamdani and Adele Welty, 'The case for a mosque a near Ground Zero', New York Daily News, 13 May 2010, p. 22.

37. Laurie Goodstein, 'In US, echoes of rift of Muslims and Jews', New York Times, 12 September 2001, p. 12.

38. Laurie Goodstein and Gustav Niebuhr, 'Attacks and harassment of Arab Americans increase', New York Times, 14 September 2001, p. 14; Matthew Purdy, 'For Arab-Americans, flag-flying and fear', New York Times, 14 September 2001, p. 14.

39. 'In their words: proud Sikh can't forget the backlash', Seattle Post-Intelligencer, 11 September 2002, p. A13.

40. Goodstein and Niebuhr, 'Attacks and harassment of Arab Americans increase'.

41. Smith, Islam in America, pp. 188-9.

42. Ibid.

43. Ibid.

44. Howard Kurtz, 'Clonaid, generating at least one kind of copy', Washington Post, 6 January 2003, p. C01.

45. Mark Steel, 'Tea Party jihad against Muslims', Muslim Observer website, 2 September 2010, http://muslimmedianetwork.com/mmn/?p=6789, accessed 14 May 2012.

46. 'Obama under fire over Ground Zero mosque', SBS World News website, 16 
August 2010, http://www.sbs.com.au/news/article/1328302/Obama-under-fireover-Ground-Zero-mosque, accessed 14 May 2012.

47. 'Obama defends Ground Zero mosque', SBS World News Australia website, 15 August 2010, http://www.sbs.com.au/news/article/1327712/Obama-defendsGround-Zero-mosque, accessed 14 May 2012.

48. 'Obama under fire over Ground Zero mosque'.

49. Malik Miah, 'United States: behind anti-Muslim hysteria', Green Left, 5 September 2010.

50. 'Obama defends Ground Zero mosque'.

51. Ibid.

52 'Muslim community center in Lower Manhattan (Park51)', New York Times website, 30 March 2011, http://topics.nytimes.com/top/reference/timestopics/ organizations/p/park51/index.html, accessed 14 May 2012.

53. See Esposito, The Future of Islam, p. 30.

54 Mehdi Hasan, 'Fear and loathing in Manhattan', New Statesman, 1 November 2010, p. 22.

55. 'Muslim community center in Lower Manhattan (Park51)'.

56. 'Obama under fire over Ground Zero mosque'.

57. 'Obama defends Ground Zero mosque'.

58. Steel, 'Tea Party jihad against Muslims'.

59. 'Pastor's rant vs. mosque. plans “9-11 Christian center", New York Daily News, 3 September 2010, p. 12.

60. Lukas I. Alpert, 'Bill Keller, Muslim-hating pastor, wants to build Christian center to rival "Ground Zero mosque" ', New York Daily News website, 5 September 2010, http://articles.nydailynews.com/2010-09-05/local/27074615_1_mosquechristian-center-ground-zero, accessed 14 May 2012.

61. 'US church vows Koran burning will go on', West Australian, 8 September 2010.

62. Jeffrey T. Kuhner, 'Ban Koran-burning? If Islam becomes a protected faith, free expression will be no more', Washington Times, 8 April 2011, p. B01.

63. James Bone, 'American dream is shattered, says Muslim attacked by a knifeman', The Times, 27 August 2010, p. 1.

64. Bobby Ghosh, 'Islam in America', Time, 30 August 2010, pp. 16-22, see p. 17.

65. Ibid., p. 19.

66. Ibid.

67. Islam and Switzerland: The Return of the Nativists, Economist Intelligence Unit, 11 December 2009, p. 11.

68. Steven Erlanger and Maïa de la Baume, 'French panel debates secularism and Islam', New York Times, 6 April 2011, p. 9.

69. 'Report: few U.S. Muslims radical', Herald Sun (Melbourne), 7 January 2010.

70. Richard Kiely, Frank Bechhofer, Robert Stewart and David McCrone, 'The markers and rules of Scottish identity', Sociological Review 49:1 (2001), pp. $33-55$, at p. 36. 
71. Fiona M. Douglas, Scottish Newspapers, Language and Identity (Edinburgh: Edinburgh University Press, 2009), p. 11.

72. Ibid., p. 19.

73. Richard Jenkins, Social Identity, 3rd edn (London: Routledge, 2008), p. 18.

74. Ibid. p. 41.

75. Paul Gilroy, 'Diaspora and the Detours of Identity', in Kathryn Woodward (ed.), Identity and Difference (London: Sage, 1997), pp. 299-343, see pp. 301-2; see also Jenkins, Social Identity, p. 21.

76. Peter J. Burke and Jan E. Stets, Identity Theory (Oxford: Oxford University Press, 2009), p. 127.

77. Shahnaz's view came from a purely religious perspective and she interpreted the Quranic verses on covering the head. However, whether Muslim women's hijab is a religious requirement or a cultural identity has been a debatable issue. Some scholars observe that it is more cultural than religious. They argue that the Quran emphasises modesty. They say that veiling was prevalent in pre-Islamic times during the Byzantine era; later it was viewed as an appropriate expression of the Quran. In the colonial period, the Muslim women's veil became a symbol of resistance, particularly in Egypt, and over the years the veil has become a symbol of Islamic self-assertion and a rejection of western cultural hegemony. See for example, Leila Ahmed, Women and Gender in Islam: Historical Roots of a Modern Debate (New Haven, CT: Yale University Press, 1992); Jonathan Bloom and Sheila Blair, Islam: A Thousand Years of Faith and Power (New Haven, CT: Yale University Press, 2001); John L. Esposito (ed.), The Oxford Dictionary of Islam (New York: Oxford University Press, 2003); Randa Abdel-Fattah, Does My Head Look Big in This? (Sydney: Pan Macmillan Australia, 2005); Karen Armstrong, 'My years in a habit taught me the paradox of veiling', Guardian website, 26 October 2006, http://www.guardian.co.uk/commentisfree/2006/ oct/26/comment.politics1, accessed 15 May 2012.

78. Stuart Hall, 'Introduction: Who Needs “Identity" ?', in Stuart Hall and Paul du Gay (eds), Questions of Cultural Identity (London: Sage, 1996), pp. 4-5.

79. Ibid. See also Steph Lawler, Identity: Sociological Perspectives (Cambridge: Polity Press, 2008), p. 3.

80. Stuart Hall, 'The Question of Cultural Identity', in The Polity Reader in Cultural Theory (Cambridge: Polity Press, 1994), p. 122.

81. Burke and Stets, Identity Theory, pp. 160-1.

82. Ibid. See also Sheldon Stryker, 'Integrating Emotion into Identity Theory', Advances in Group Processes 21 (2004), pp. 1-23.

83. Henri Tajfel (ed.), Human Groups and Social Categories: Studies in Social Psychology (Cambridge: Cambridge University Press, 1981); Henri Tajfel and John C. Turner, 'The Social Identity Theory of Intergroup Behaviour', in Stephen Worchel and William G. Austin (eds), Psychology of Intergroup Relations, 2nd edn (Chicago: Nelson-Hall 1986), pp. 7-24.

84. Kabir, Young British Muslims. 
85. Jenkins, Social Identity, pp. 112-13.

86. Lawler, Identity, p. 3.

87. Ibid. pp. 143-4.

88. 'Islamo-fascism Awareness Week', Terrorism Awareness Project website, http:// www.terrorismawareness.org/islamo-fascism-awareness-week/, accessed 15 May 2012.

89. Avtar Brah, 'Non-binarized Identities of Similarity and Difference', in Margaret Wetherell, Michelynn Laflèche and Robert Berkeley (eds), Identity, Ethnic Diversity and Community Cohesion (London: Sage, 2007), pp. 136-45, at pp. 143-4.

90. Ibid., p. 144.

91. See Dilwar Hussain, 'Identity Formation and Change in British Muslim Communities', in Margaret Wetherell, Michelynn Laflèche and Robert Berkeley (eds), Identity, Ethnic Diversity and Community Cohesion (London: Sage, 2007), pp. 34-9; Tariq Modood, Multiculturalism: A Civic Idea (Cambridge: Polity Press, 2007); S. Sayyid and AbdoolKarim Vakil (eds), Thinking through Islamophobia: Global Perspectives (London: Hurst, 2010).

92. Muslim Americans, pp. 11, 34.

93. Nahid A. Kabir, 'Why I Call Australia "Home”? A Transmigrant's Perspective', M/C Journal 10:4 (2007); Kabir, Young British Muslims.

94. Sally Howell and Amaney Jamal, 'The Aftermath of the 9/11 Attacks', in Detroit Arab American Study Team, Citizenship and Crisis: Arab Detroit after 9/11 (New York: Russell Sage Foundation, 2009), pp. 69-100; see p. 72.

95. Ali M. Kettani, Muslim Minorities in the World Today (London: Mansell, 1986).

96. 'From Pakistan to the world', pp. 19-21.

97. Barney G. Glaser and Anselm L. Strauss, The Discovery of Grounded Theory: Strategies for Qualitative Research (Chicago: Aldine, 1967).

98. Kathy Charmaz, Constructing Grounded Theory: A Practical Guide through Qualitative Analysis (London: Sage, 2006).

99. Brigid Schulte, '5 Virginia men facing terrorism charges in Pakistan write of “noble” motivation', Washington Post, 16 May 2010, p. 12.

100. Letter dated 4 January 2010. 